\title{
Sumpah Pemuda dan Revitalisasi Nilai Kearifan Lokal
}

\author{
Wendi Abmad Wabyudi
}

Peristiwa Sumpah Pemuda merupakan sebuah yang sangat peristiwa penting dalam perjalanan Indonesia menjadi sebuah bangsa (nation). Peristiwa penting yang digerakkan oleh anak-anak muda Indonesia yang terjadi pada 88 tahun silam. Bahkan salah seorang sejarawan senior (Taufik Abdullah) tak segan-segan meletakkannya sebagai salah satu dari "Tiga Peristiwa Satu Napas"-Sumpah Pemuda 28 Oktober 1928, Proklamasi 17 Agustus 1945, dan Peristiwa 10 November 1945 (Abdullah, 2015). Meletakkan peristiwa Sumpah Pemuda sebagai salah satu dari elemen penting dari napas Indonesia bukan tanpa alasan. Sebab, pada momen inilah para pemuda-pemudi Indonesia menanggal sekat-sekat suku, agama dan ras, dan kemudian berikrar untuk sebuah persatuan dengan menyatakan diri sebagai bagian dari komunitas yang bertumpah darah yang satu, tanah Indonesia; berbangsa yang satu, bangsa Indonesia; dan menjunjung bahasa persatuan, bahasa Indonesia. Peristiwa inilah yang kemudian menjadi awal lahirnya identitas kebangsaan kita yang nantinya mengerucut menjadi nasionalisme Indonesia sendiri.

Satu hal yang perlu kita garis bawahi dari peristiwa ini adalah bahwa generasi muda sangat menentukan gerak sejarah dari sebuah bangsa. Tak salah rasanya bila Soekarno meneriakkan "beri aku sepuluh pemuda, maka akan ku guncang dunia", karena memang lokomotif dari sebuah perubahan itu sendiri berada di tangan generasi muda. Termasuk nasib bangsa ini. Sejarah Indonesia telah mencatatnya. Hal itulah yang harus benar-benar menjadi kesadaran sejarah bagi generasi muda Indonesia hari ini.

Untuk Sumatera Barat (baca Minangkabau) sendiri, generasi mudanya bukanlah wajah asing di kancah pergerakan kebangsaan Indonesia. Bahkan Majalah Tempo tak sungkan-sungkan menyebut tiga dari empat Bapak Pendiri bangsa Indonesia adalah anak muda dari Minangkabau. Ada Tan Malaka, M. Hatta, dan Sutan Sjahrir. Satu-satunya yang bukan anak muda Minangkabau cuma Soekarno. Selain itu, masih banyak lagi anak-anak muda Minangkabau yang menjadi tokoh di kancah nasional, sebut saja M. Yamin, H. Agus Salim, Hj. Rasuna Said, M. Natsir, HAMKA, dst.

Setelah kita berkunjung pada era-era generasi emas anak muda Minangkabau. Mari kita refleksikan pada realitas generasi Minangkabau hari ini. Maka kita akan menemukan krisis tokoh di kancah nasional, rongrongan korupsi yang menyapa Ranah Minang-korupsi berjamaah lebih 
tepatnya-, merosotnya moral generasi muda, dst. Itulah beberapa hal-hal yang menjadi wajah Minangkabau hari ini.

Mengapa hal itu bisa terjadi? Ada apa dengan generasi muda Minangkabau? Itulah beberapa pertanyaan yang sering terlontar dari mulut kita dan masyarakat Indonesia yang tahu akan sejarah. Namun pertanyaan-pertanyaan itu sepertinya dibiarkan sekadar pertanyaan saja. Namun tak pernah benar-benar serius untuk duduk bersama mencari akar permasalahannya serta solusinya. Walaupun perorangan sudah mencoba untuk menawarkan pemikirannya, seperti Buya Mas'oed Abidin melalui konsep “Tiga Sepilin”-nya.

Secara garis besar generasi muda Indonesia, khususnya Sumatera Barat menurut hemat penulis sedang didera oleh tiga penyakit, yaitu: 1) tercerabut dari akar budaya dan agama (disrupsi); 2) tidak punya tujuan (disorientasi); 3) mulai berpindah dari kehidupan sosial dan kultur bangsa sendiri ke kehidupan sosial dan kultur bangsa lain (dislokasi). Penyakit-penyakit inilah yang memberi ruang pada generasi muda untuk terhegemoni dengan budaya pop dan westernisasi.

Untuk itu, perlunya sebuah gagasan bersama untuk meredam virus budaya pop dan westernisasi tersebut. Salah satu caranya, yaitu dengan merevitalisasi nilai-nilai kearifan lokal yang kita miliki sebagai sebuah filter virus tersebut. Salah satu dari sekian banyak nilai-nilai kearifan lokal yang dimiliki Minangkabau, penulis menawarkan revitalisasi atas falsafah "Tigo Tungku Sajarangan".

Falsafah "Tigo Tungku Sajarangan" sebenarnya bukan hanya sekadar bermakna pada struktur kepemimpinan yang menuntun masyarakat Minangkabau. Tapi lebih merupakan tiga nilai yang harus menjadi pegangan yang menuntun pribadi masyarakat Minangkabau. Ketiga unsur tersebut, yaitu Niniak Mamak, Alim Ulama, dan Cadiak Pandai. Dalam tataran adminstrasi tradisional masyarakat Minangkabau Niniak Mamak bermakna Pangulu atau tokoh 'Adat', Alim Ulama merupakan orang yang menguasai ilmu agama atau tokoh agama, dan Cadiak Pandai merupakan kaum cendikiawan. Namun selama ini kita memahaminya hanya sebatas tataran pada fungsinya sebagai administrasi tradisional saja, kita lupa bahwa ada makna yang lebih dari sekadar pengertian adiministrasi tradisional semata di dalamnya. Jika kita pahami lebih dalam, sebenarnya falsafah tersebut lebih kepada pegangan hidup untuk masing-masing individu di Minangkabau. Tungku yang pertama yaitu Niniak Mamak yang merupakan memuat nilai 'Adat' atau Culture (alam takambang jadi guru). Tungku yang kedua adalah Alim Ulama yang memuat akan nilai Agama, dan tungku yang ketiga yaitu Cadiak Pandai yang memuat nilai ilmu pengetahuan. Ketiga hal inilah yang yang dulunya saling beririsan untuk menghasilkan sebuah harmoni yaitu produk manusia Minangkabau yang menjadi tokoh bangsa. 
Hal ini juga pernah diungkapkan oleh Audrey Kahin-seorang Indonesianis yang menfokuskan kajian tentang Sumatera Barat-bahwa generasi emas Minangkabau lahir dari ketiga irisan tersebut. Generasi yang ia sebut sebagai "pos terdepan republik" (Tan Malaka, M. Hatta, Sutan Sjahrir, H. Agus Salim, M. Yamin, Hj. Rasuna Said, HAMKA, dst). Namun ia lebih mengecilkan pada konteks pendidikan, yaitu pendidikan adat, pendidikan surau, dan pendidikan barat (Kahin, 1990).

Yang terjadi hari ini kita tak lagi dinaungi harmonisasi "Tigo Tungku Sajarangan" tersebut. Kita seperti terhegemoni oleh perkembangan Iptek belaka, sedangkan nilai 'Adat' dan 'Agama' yang seharusnya menjadi filter dan penyeimbang kini mulai tercerabut dari akar kita. Virus kegandrungan akan budaya pop dan westernisasi sudah menjadi hal yang lumrah kita temui hari ini. Pada akhirnya kita malah terjebak pada keadaan malu akan culture sendiri dan berusaha keras membuangnya jauh-jauh. Ujug-ujugnya malah dengan bangga mengadopsi gaya hidup dan kultur yang bukan milik kita.

Pada usia Sumpah Pemuda ke 88 tahun ini, seraya mengingat sejarah mari kita gelorakan semangat dari Sumpah Pemuda tersebut. Semangat yang menggelora untuk merevitalisasi nilainilai kearifan lokal dan menjemput kembali dua tungku yang telah mulai mengikis atau mungkin telah hilang. Untuk sebuah tekad melahirkan kembali generasi emas Minangkabau Jilid II.

Padang, 28 Oktober 2016 